\title{
Applied implications for food marketing, quality assurance and control: an approach based on analyzing consumer attitudes and behavior
}

- Ho Huy Tuu ${ }^{\mathrm{a}^{*}}$

- Le Nguyen Hau

(a) Nhatrang University, Khanhhoa, Vietnam

(b) Ho Chi Minh City University of Technology, VNU-HCM, Vietnam

*Email: tuu_hohuy@yahoo.com

(Manuscript Received on August $5^{\text {th }}$, 2014; Manuscript Revised December $5^{\text {th }}$, 2014)

\begin{abstract}
Purposes - This paper presents the idea that food quality management and control should be based on marketing orientation perspectives. It aims to explore the cues, reasons, criteria and sources of perceived quality and food risks, then investigates their influences on consumer satisfaction and consumption toward food (fish) in Vietnam. Finally, it recommends some directions for future research in both food marketing and Quality Control.

Methods - This presentation is based on a range of research studies using different data sets collected across provinces in Vietnam, and using different methods to analyze the data and test constructs, hypotheses and models.

Findings - First, it indicates that nutrition and taste occupy the highest ratio explaining for positive attitudes (positive perceived quality), while safety and negative feelings are dominated to explain negative attitudes (food risks). Consumers with more positive (negative) reasons have a higher (lower) consumption. Second, perceived quality as a a multidimensional construct is found to have a

positive effect on consumer satisfaction, while negative feelings have a negative effect on satisfaction. Perceived price has no a significant influence on satisfaction but a significant positive effect on perceived quality. The results also show that there are four groups of reasons causing food risks coming from producers, sellers, consumers and products. Perceived food risk is found to have an indirect effect on consumption via consumer satisfaction, and negatively moderate the satisfactionconsumption relationship. However, the effect of perceived risks is weaker when consumer knowledge increases. Finally, ambivalence is found to have a negative direct effect on both satisfaction and health involvement. Both ambivalence and health involvement are found to moderate the satisfaction-consumption relationship in a complex mechanism.

Managerial implications - Managers and marketers should pay attention to reasons for consumer attitudes and consumption and have a multidimensional view of food quality and risk. Marketing strategies, which reduce consumer risks and educate them with relevant knowledge,
\end{abstract}


may be effective strategies to increase consumption. For Quality Control, it is important that they must understand not only the established sensory standards for product quality, but also know, if possible, consumer expectations of sensory evaluations particularly at target markets pursed by a food company. Quality Control must understand all the traceable systems from raw material sourcing to finished products, and find and prevent all kind of tricks and methods that producers, processors and sellers use to avoid or even go around the specifications for the lack of the right raw material at the right time. It is important to recruit Quality Control Inspectors who can do all this right and have the basic knowledge.

Limitation and future research - This paper focuses on only fish. Future research should expand to other foods and try to answer

Keywords: food quality and risk, consumer satisfaction, consumption, fish, quality control.

\section{INTRODUCTION}

Modern consumer no longer has reactive behavior towards a product but a more proactive approach, and consumer needs and the market requirements are more complex when taking into account the subjectivity in consumer's needs and desires [1]. Therefore, the paper focuses on the idea that the management of food quality and food safety or risk should based on marketing orientation perspectives. This means that through marketing/market research studies, marketers and managers can understand the cues, criteria, reasons and sources which consumers use to evaluate food quality as well as the sources of food risk and send their undersdandings to operation department to produce food products to fulfil consumers's needs to satisfy them [2].

Two approaches will be considered in the evaluation of food quality: The analysis of objective quality measured by chemical analysis, and the analysis of subjective quality measured by the following research questions: Do the certainty or stability of perceived quality affect and/or interact with consumer satisfaction to increase consumption/loyalty? Do perceived food quality and perceived price interact to influence consumer satisfaction and consumption? Do perceived food quality and perceived risk interact to influence consumer satisfaction and consumption? What form of risk interacts with what dimension of perceived quality to influence consumer satisfaction and consumption? How can each kind of consumer knowledge help to decrease the negative effects of food risks? How can Quality Control and quality programs be built to solve the problems of fishing vessels, farmers, processors, marketing sectors and the consumers, and to increase the consumer's security in health and nutritional values. consumers' perceptions [3]. Morgan [4] says there is a difference in quality perception between the manufacturer and the consumer's point of view and it is the reason why it has to be analyzed from the consumer's viewpoint because they are the purchasers and the last level in the value chain. This approach has been designated "Perceived Quality Approximation" [5] highlighting that judgments on quality depend on perceptions, needs and consumer objectives.

This Perceived Quality Approximation approach is also integrated into the Total Food Quality Model that is an attempt to provide a common framework to understand how the perceptions of food quality and food safety or risks impacting on consumer attitudes and food choice [2]. This model proposes two major dimensions along which we can analyze consumers' perceptions of food quality and food safety or risk: a horizontal and a vertical dimension. The horizontal 
dimension is a time dimension: it distinguishes the perceptions of food quality and food safety or risk before and after purchase as well as consumer satisfaction and repurchasing probabilities [6]. The vertical dimension deals with how consumers infer food quality and safety from a variety of signals or cues, and with how consumers find out which properties of a food product are desirable by linking them to basic motivators of human behavior [7].

Perceived quality is a multidimensional construct [3,8-10]. In food area, previous studies also sugest that perceived food quality may include 4 dimensions: taste quality, nutritious quality, safe quality and convenience quality [11-13]. Taste quality is the food-attribute evaluations by the perceptions of tatste, texture, smell, appearance [14]. Nutritious quality relates to the perception of food health [15]. Safe quality is the characteristics of food safety [11]. Convenience quality is reflected by easy to use, savings of time and effort $[3,16]$. Previous studies show that all four dimensions of perceived quality have influences on food satisfaction and food consumption or choice [14,15,17-23].

However, food attitudes and choice is often influenced more by the psychological interpretation of product properties than the physical properties of products themselves [24], and the perception of food risk is one such psychological interpretation $[25,26]$. Food quality and food risks are really the two sides of a coin and related with each other $[7,11,26]$. Similar to food quality, we can distinguish objective from subjective food risk. Objective food risk is a concept based on the assessment of the risk of consuming a certain food by scientists and food experts. Subjective food risk is in the mind of the consumer [7]. Food risk is also a multidimensional contruct that includes the components of financial, psychological, social, performance, physical and time-related risks $[25,27]$. Financial food risk is related to losing or wasting income; Performance food risk is the status that food product does not meet the need; Physical food risk causes personal illness, injury or health issues; and Psychological food risk involves emotional pressure or social losses associated with a purchase decision [26,28,29]. Previous studies also indicate that the perceptions of food risk affect consumer food attitudes and choice in ways that are opposite with from perceptions of the other dimensions of quality we have distinguished above [7].

This paper integrates the above different perspectives of assessing food quality and risk to understand how consumers perceive food quality and risk as well as their influences on consumer attitudes, satisfaction and consumption. Therefore, this paper first describes the dimensions of perceived quality and the sources of food risks, then, investigates their influences on consumer attitudes, satisfaction and consumption/loyalty toward food in Vietnam. Because the two-side nature of food quality and food safety or risk, consumers who involve their health may feel ambivalent about food by its negative aspects such as risks. What are the consequences they receive depending much on their knowledge and skills of evaluating, choosing, preparing and cooking. Therefore, the paper will go further by investigating the relationship between food attitudes/satisfaction and consumption with the presence of the different roles of ambivalence, involvement, consumer knowledge, perceived risks in the relationship. Finally, it recommends some managerial implications for food marketers, managers and especially for Quality Control to assure and control food product quality. It also discusses some limitations and future research.

This paper focuses on consumer satisfaction, loyalty and the relationship between these two contructs as dependent variables. This is important 
because the concept of consumer satisfaction occupies a central position in marketing thought and practice and is a major outcome of marketing activity [30]. Satisfaction is suggested to link processes culminating in purchase and consumption with postpurchase phenomena, such as loyalty [31]. However, satisfaction may often be "a matter of picking a lowhanging fruit" and a "trap" for marketers and managers [32] because satisfied customers are not necessarily loyal [33] and dissatisfied customers do not always defect [34]. This approach not only contributes to a deeper understanding of the nature of the satisfaction-loyalty relationship, but also highlights the role of perceived quality and food risk, satisfaction strength's properties (e.g. consumer knowledge, involvement, ambivalence...) as drivers and/or barriers of consumer satisfaction and in moving from consumer satisfaction to their loyalty toward the products. The general research model is shown in Figure 1.

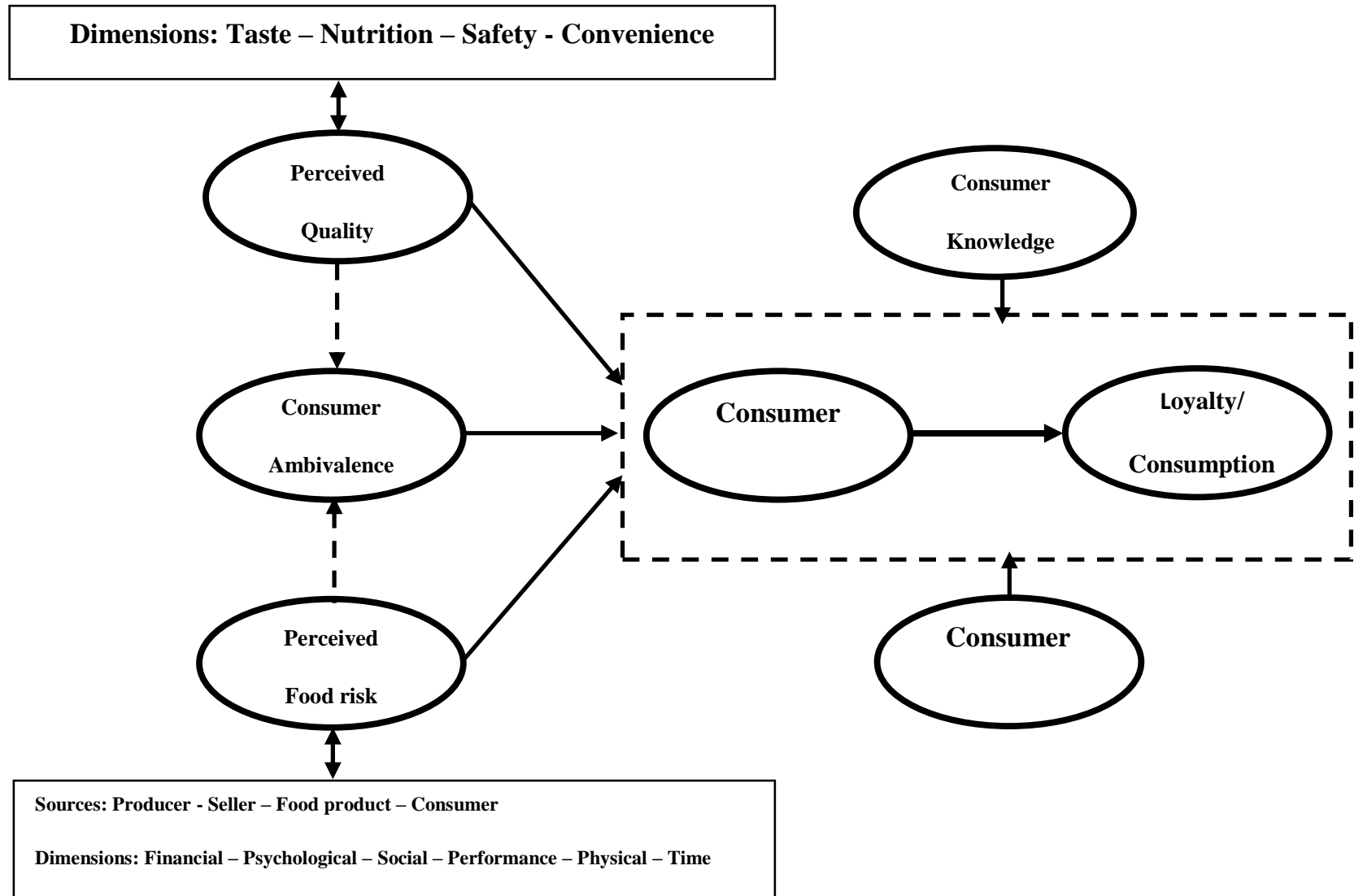

Figure 1. The general theoretical mode

\section{METHODS}

Among food categories in Vietnam, fish occupies about one third in domestic consumption volume, and keeps the first position in national export value. Fish is also diversified in species and has the most basic characteristics of a representative food type.
Therefore, the paper focuses on fish, which I believe that the findings are totally generalized to other foods. This paper is based on 6 research studies. Study 1 explores the reasons of both positive and negative evaluations of perceived quality explaining 
for attitudes, as well as tests their effects on consumption behavior and the attitude-behavior consistence of consumers towards fish. Study 2 investigates the role of perceived quality, perceived price and negative feelings affecting fish consumer satisfaction. Study 3 explores the sources of risks focusing on fish products. Studies 4 and 5 focus on the relationships between attitudes/satisfaction and fish consumption with the presence of the different roles of perceived food risks and consumer knowledge in the relationship. Study 6 explores the combined role of ambivalence and consumer involvement on the relationship between satisfaction and fish consumption. Therefore, different data sets were collected across provinces in Vietnam, and different methods were used to analyze the data. Table 1 provides information related to the research designs, data sources, respondents, products and methods.

The next part, I will present the findings and practical implications.

Table 1. Research designs, sampling details and methods

\begin{tabular}{|c|c|c|c|c|}
\hline Study & Places/Products & Sample size & Collection method & Analytical methods \\
\hline 1 & Khanhhoa Fish & 361 consumers & $\begin{array}{l}\text { Face-to-face, at home, } \\
\text { questionnaire, fish }\end{array}$ & $\begin{array}{l}\text { Descriptive statistics, } \\
\text { multiple regression }\end{array}$ \\
\hline 2 & Nhatrang Fish & 250 consumers & $\begin{array}{l}\text { Face-to-face, at home, } \\
\text { questionnaire, fish }\end{array}$ & $\begin{array}{l}\text { Structural equation } \\
\text { modeling (SEM) }\end{array}$ \\
\hline $3,4 \& 5$ & $\begin{array}{l}\text { Nhatrang Fish } \\
\text { Hanoi Fish }\end{array}$ & $\begin{array}{l}20 \text { students } \\
100 \text { consumers } \\
392 \text { consumers }\end{array}$ & $\begin{array}{l}\text { In depth interview } \\
\text { Face-to-face, at market, } \\
\text { questionnaire, fish } \\
\text { Face-to-face, at market, } \\
\text { questionnaire, marine fish }\end{array}$ & $\begin{array}{l}\text { Qualitative analysis } \\
\text { Descriptive statistics } \\
\text { SEM }\end{array}$ \\
\hline 6 & $\begin{array}{l}\text { Nhatrang, HCM city, } \\
\text { Cantho }\end{array}$ & 922 consumers & $\begin{array}{l}\text { Face-to-face, at home, } \\
\text { questionnaire, fish }\end{array}$ & SEM \\
\hline
\end{tabular}

\section{FINDINGS AND SUGGESTIONS}

\subsection{Study 1: Analyzing the reasons for consumer attitudes toward fish products}

Firstly, the paper explores the reasons of both positive and negative evaluations of perceived quality explaining for consumer attitudes, as well as tests their effects on consumption behavior and the attitude-behavior consistence of consumers towards fish products. We carry out the study based on two following perspectives:

(1) Perceived quality is a multidimensional construct including four dimensions: taste, nutrition, safety and convenience [11-13].

(2) Analyzing the reasons of consumer attitudes (perceived quality, perceived risks) is based on attitude strength theory that the reason analysis helps to increase the predictive power of attitudes to behavior because consumer will have a deeper cognitive process about the attitude through the process of reason analysis [35,36]. This means that the more reasons is given to explain consumer attitude, the stronger the attitude is. In addition, consumer is always ambivalent (i.e., is both positive and negative) in their thoughts, feelings and emotions about foods they use [37,38]. Therefore, while the relative amount of positive reasons keeps a role as a facilitating factor, the realative amount of negative reasons keeps a role as barrier factor of the behavior [16,39].

Based on the above theoretical perspectives, our study indicates that nutrition quality and taste quality occupy the highest ratio explaining for positive attitudes $(63.2 \%)$ (Table 2a). In contrast, the food safety quality and inconvenience quality (33.2\%) and 
negative feelings $(35.3 \%)$ are dominated to account for negative attitudes (Table 2b).

The results also indicate that consumers with more reasons for their positive attitudes have a higher consumption behavior and a more consistence between their attitudes and behavior. By contrast, consumers with more reasons of their negative attitudes have a lower consumption behavior. However, this amount of negative reasons does not affect he attitude-behavior relationship.

Table 2a. Analyzing the reasons for consumer positive attitudes toward fish

\begin{tabular}{lll}
\hline Reasons for positive attitudes & Frequency & $\mathbf{\%}$ \\
\hline Taste quality: good taste, attractive appearance, good texture, good smell & $\mathbf{5 2 8}$ & $\mathbf{3 5 . 2}$ \\
Nutritious quality: good for health, high nutrition, easy to digest, weight control & $\mathbf{4 2 0}$ & $\mathbf{2 8 . 0}$ \\
$\begin{array}{l}\text { Convenient quality: easy to cook, many meals, available, little time to cook, diversity of } \\
\text { recipes, different kinds of fish }\end{array}$ & 182 & 12.1 \\
Safety quality: natural, no chemist, no obesity, alive fish & 52 & 3.5 \\
Price: wide range upon kinds of fish, reasonable, relative cheap, high value for money & 165 & 11.0 \\
$\begin{array}{l}\text { Consumer knowledge: know how to evaluate fish quality, the ways to cook, choosing fresh } \\
\text { fish }\end{array}$ & 151 & 10.1 \\
Total number of reasons & 1498 & 100.0 \\
\hline
\end{tabular}

Table 2b. Analyzing the reasons for consumer negative attitudes toward fish

\begin{tabular}{lll}
\hline Reasons for negative attitudes & Frequency & $\mathbf{\%}$ \\
\hline $\begin{array}{l}\text { Taste quality: bad taste (unsavory), bored appearance, bad texture (soft, overripe), } \\
\text { unattractive smell }\end{array}$ & 166 & 11.7 \\
$\begin{array}{l}\text { Nutritious quality: fatty } \\
\text { Convenient quality: difficult to reserve, constantly observation in cooking, taking time in }\end{array}$ & $\mathbf{1 7 6}$ & 6.6 \\
buying and choosing process, easy to make a wrong choice & $\mathbf{2 9 6}$ & $\mathbf{2 0 . 8}$ \\
Safety quality: dirty, bacteria, chemical substance, poisons, disease, allergy & $\mathbf{5 0 2}$ & $\mathbf{3 5 . 3}$ \\
Negative feelings: many scales, bad smell, bones & 96 & 6.7 \\
Price: fluctuation, unstable, difficult to compare, change depending places and times to buy & & 6.6 \\
Consumer knowledge: lack of cooking skills, know only some kinds of fish and meals, & 94 & 100.0 \\
recipies & 1424 & 2 \\
Total number of reasons
\end{tabular}

Table 3. Testing the effects of the amount of positive and negative reasons on fish consumption behavior and the attitudebehavior relationship

\begin{tabular}{|c|c|c|c|c|c|}
\hline \multirow{2}{*}{ Independent variables } & \multicolumn{2}{|c|}{ Unstd. Coefficients (B) } & \multirow{2}{*}{$\begin{array}{l}\text { Std. Coefficients } \\
(\beta)\end{array}$} & \multirow{2}{*}{$\mathbf{t}$ - values } & \multirow{2}{*}{$\mathbf{P}$} \\
\hline & Values & Std. errors & & & \\
\hline Constant & 5.86 & 0.14 & & 41.1 & 0.00 \\
\hline Attitudes & 0.76 & 0.11 & 0.34 & 6.9 & 0.00 \\
\hline Positive reasons & 0.41 & 0.07 & $\mathbf{0 . 3 3}$ & 5.7 & 0.00 \\
\hline Negative reasons & -0.29 & 0.08 & -0.18 & -3.6 & 0.00 \\
\hline Attitudes x Positive reasons & 0.14 & 0.05 & 0.15 & 2.9 & 0.00 \\
\hline Attitudes x Negative reasons & -0.04 & 0.06 & -0.03 & -0.7 & 0.49 \\
\hline
\end{tabular}

Dependent variable: Fish consumption behavior; $R^{2}=38.4 \%, F=37.9, p<0.001$. 
The findings suggest that managers and marketers should pay attention to the reasons for consumer attitudes. Positive reasons should be considered as important information to determine factors which managers can base on to build the communication strategy to consolidate consumer attitudes, while managers should try to eliminate or limit negative reasons as minimum as possible to improve product quality as well as keep favorable attitudes and remain consumption toward the fish products.

\subsection{Study 2: Testing the effects of perceived} quality, price and negative feelings on consumer satisfaction

As presented in the first study, the aspects of perceived quality are main reasons for food/fish attitudes and consumption. Especially, as mentioned above, perceived quality is structured as a multidimensional construct with four dimentions: taste, nutrition, safety and convenience [11-13]. In addition, negative feelings (negative attributes of products, such as bones, smell...) [16] and perceived price [40] are important factors for consumer attitudes. Based on the above results, this presentation explores further the role of perceived quality, price, negative feelings impacting on consumer satisfaction. The findings indicate that perceived quality has a positive effect, while negative feelings have a negative effect on satisfaction. Perceived price has no a significant influence on satisfaction but a significant positive effect on perceived quality.

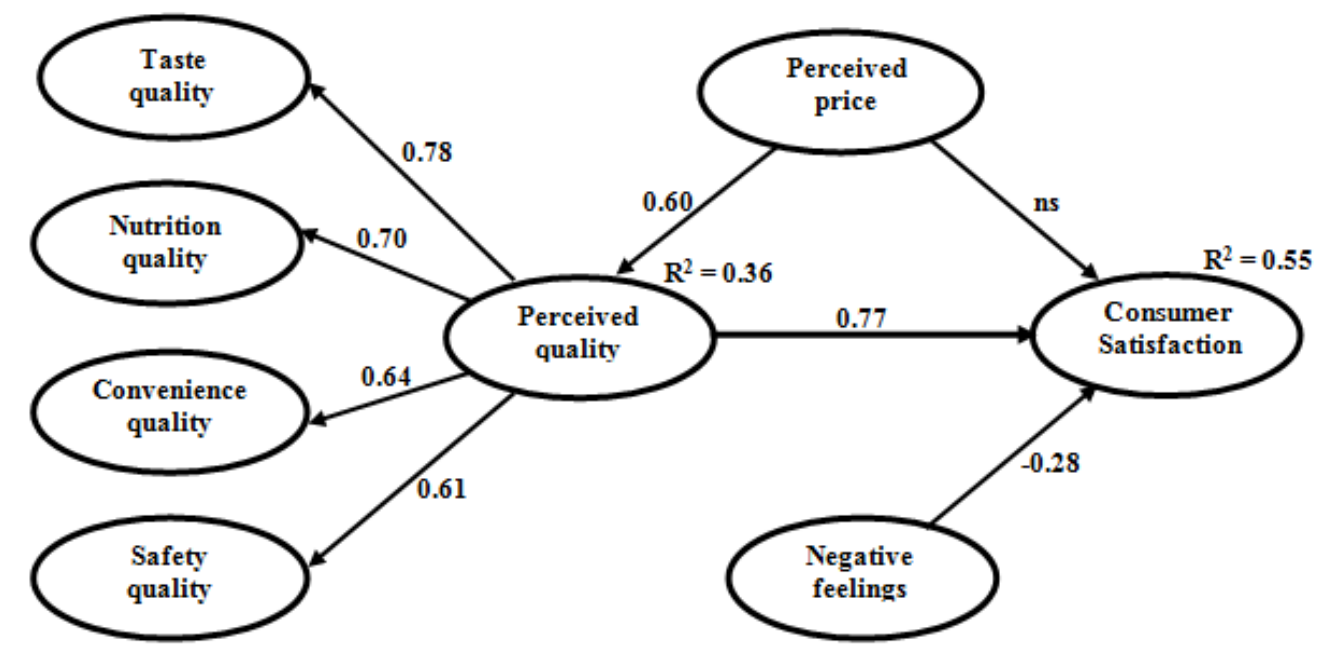

Figure 2. The structural relationships between perceived quality, negative feelings, price and satisfaction

The above discussions and findings about perceived quality come from consumer cognitive process, which inputs are mainly based on consumer sensory evaluations and experiences about the food products. Because the main tools for the beginning of all Quality Control are the senses by smelling, seeing, feeling, tasting and even hearing, it is important that Quality Control understands not only the established sensory standards for product quality, but also knows, if possible, consumer sensory expectations and evaluations particularly at target markets pursed by a food company. This knowledge has important meanings for Quality Control to give the company advices and help them to process, preserve and deliver products fulfilling the established standards as well as consumer expectations.

Therefore, the sight inspection of the raw materials is important to be conducted by Quality 
Control. Who does not understand how a fish, a shrimp or the like must look if good and fresh quality cannot repair this lack of raw-material quality later in the later stages of food supply chain. The raw materials must be checked by Quality Control as well as constantly control the processing for the customers or consumers demands. All five human senses are requested when it comes to Quality Control. One calls this natural Quality System of Senses a "Sensory Measure" of the food quality, and it is taught to all Control Inspectors on the Universities for Food Processing, such as in Nhatrang University in Vietnam. For example, the origin of the seafood products and the use of whatever chemicals in the farms and on the fisheries vessels must be known and monitored also by Quality Control. It is a major criterion how the product is fitting the quality expectations of customers and/or consumers. The batches of raw materials are taken into a first sight which is relied to their freshness, also to their shape and lack of damages, to their sizing and suitability for the latter products. Then the first stages of processing are followed. Slaughtering of the fresh or alive fish, presorting and treatment of shrimp products - what chemicals are allowed, what are restricted always after the general quality farms and the quality demanded by customers or consumers

As mentioned above, price levels may be not much important for marketing food products, but quality-based pricing for food products may be a better one. Quality Control is a part of the price of a product, so some people might think they can spare it. This risk can be quite costly nowadays because food products often travel a long way to their final markets and consumers. Quality Control can only take liability as much as human intelligence and knowledge allows them the adequate amount of fees. Quality Control cannot make the food products better, fresher or more delicious to enjoy, but it often and regular can avoid processing mistakes. Therefore, the Motto of all Quality Control is that "Better safe, than sorry!"

\subsection{Study 3: Exploring the sources of food risk}

Next, the paper explores the sources of food risks focusing on fish products. We carry out the study based on the following perspectives:

(1) Perceived food risks is a multidimensional construct that includes five dimensions: functional (taste, nutrition...), health (unsafe, poisonous...), time and effort (inconvenience), psychological (worried, stressful, uncomfortable...) and social risks (low image, being complained...) [28,29,41].

(2) The study is conducted in two steps. The first step is a qualitative study by personally interviewing consumers about causes or reasons that consumers think that they can cause an unsuitable or even a bad meal with fish. An unsuitable or bad meal is defined as a meal that does not taste well, wastes them time, money and effort, even harms their health. In the second step, we make a long list of causes or reasons and ask consumers to choose reasons they perceive or believe that they are main reasons explaining for an unsuitable or bad meal with fish they used to eat.

The results show that there are four groups of reasons causing food risks coming from producers, sellers, consumers themselves and chosen species of fish. The results indicate that the amount of reasons belong to the producers occupying the first ratio $(36.2 \%)$, to sellers at the second rate $(32.3 \%)$, then to fish products $(23.1 \%)$, and to consumers with the lowest ratio $(8.4 \%)$. The main reasons in the producer group include using poisons to catch fish, using chemicals to preserve, long fishing sea voyage, lacking of tools to maintain fish quality, unhygienic containers... The sellers increase food/fish risks by using special chemicals to refresh fish, unhygienic 
fish shops ... Consumers also reveals that they sometimes make an unsuitable meal with fish because of lacking of cooking skills, do not know how to evaluate fish quality, or sometimes they decide to buy new fish species for their meals and feel dissatisfied with the decisions... Finally, consumers also say that low quality fish may have lots of bones, scales, bad smell, high mercury content, contaminated by heavy metals, virus, bacteria, illness, toxin, pollution...

Table 4. Sources and reasons of food/fish risks perceived by consumers

\begin{tabular}{|c|c|c|c|}
\hline $\begin{array}{c}\text { Producers } \\
(276 ; 36.2 \%)\end{array}$ & $\begin{array}{c}\text { Sellers } \\
(246 ; 32.3 \%)\end{array}$ & $\begin{array}{l}\text { Fish products } \\
(176 ; 23.1 \%)\end{array}$ & $\begin{array}{c}\text { Consumers } \\
(64 ; 8.4 \%)\end{array}$ \\
\hline $\begin{array}{l}\text { - Using poisons to catch fish } \\
\text { - Using chemicals to } \\
\text { preserve } \\
\text { - Long fishing sea voyage } \\
\text { - Lacking of tools to } \\
\text { maintain fish quality } \\
\text { - Unhygienic containers } \\
\text { - Others }\end{array}$ & $\begin{array}{l}\text { - Using special chemicals to } \\
\text { refresh fish } \\
\text { - Unhygienic fish shops } \\
\text { - Preserving fish in a wrong } \\
\text { way } \\
\text { - Unhygienic tools and } \\
\text { means to cut and slice fish } \\
\text { - Others }\end{array}$ & $\begin{array}{l}\text { - Lots of bones, scales, } \\
\text { bad smell } \\
\text { - High mercury content } \\
\text { - Conminated by heavy } \\
\text { metals, virus, bacteria, } \\
\text { illness, toxin, pollution } \\
\text { - Others }\end{array}$ & $\begin{array}{l}\text { - Lacking of cooking skills } \\
\text { - Not know how to evaluate } \\
\text { fish quality } \\
\text { - Buying new fish species } \\
\text { - Others }\end{array}$ \\
\hline
\end{tabular}

Figure 3. The effects of perceived food risk and consumer knowledge

3.4 Study 4 \& 5: The effects of food risk and consumer knowledge on consumer satisfaction and consumption/loyalty

These studies continue the Study 3 and based on the two perspectives:

(1) The effects of perceived food risks on consumer food attitudes/satisfaction and behaviors are opposite with the ones of perceived quality $[7,26]$.

(2) Consumer knowledge is integrated to investigate as a moderator in the relationships between perceived food risk, consumer satisfaction and loyalty.
Perceived risk is found to have an indirect effect on consumption through satisfaction. Perceived risk is a negative moderator in the satisfactionconsumption relationship. Consumer knowledge proves to negatively moderate the relationship between perceived food risk and satisfaction, and positively moderate the relationship between satisfaction and loyalty toward fish products.

Based on these findings, customer management based on satisfaction is not sufficient to increase consumer consumption, especially in the situations of highly perceived risk. Marketing strategies, which reduce consumers' risks, consolidate their confidence and educate them with relevant knowledge, may be effective strategies to increase consumption. 
Management attention should focus on reducing risks with which consumers may be faced through producing fresh or safe fish products, and communicating broadly safe signals of their products. Communication strategy should focus much more on improving knowledge and signing food safety for consumers with lower knowledge than the higher knowledge.

In addition, food quality assurance must understand the sources of risks faced by consumers. While producers and sellers need to recognize their responsibility in fishing, farming, processing, storing and selling by safe methods, consumers need to be educated the skills and knowledge of cooking, preserving and quality evaluation. Quality Control must understand all the traceable systems from raw material sourcing through to the arrival of the products in the factory, through all processing stages until the finished products. Quality Control or Quality Control Inspectors specifically should also find and prevent all kind of tricks and methods that producers, processors and sellers use to avoid or even go around the specifications for the lack of the (specified and requested) right raw material at the right time.

The biggest problem occurring in the food industry and for the Quality Control is that all kinds of chemical threats and contaminations can occur from raw material to finished product stage. These threats are natural but often also self-inflicted through lack of hygiene or treatment methods in the process conducted outside of the legal regulations. These hazards include environmental contaminations, medical treatment residues, lack of hygiene and enhancing and preserving chemicals. The first three mentioned must be avoided in every stage of the process beginning with harvesting or fishing the raw material down to the finished product. The latter must be tightly controlled as it is depending on voluntary actions and practices inside the processing factory. Quality Control must be aware of all these kinds of threats, but can often be avoided through change of hygiene and treatment regulations and habits inside the processing factor. As one is acting with a decaying situation with a lot of chemical influences taking part in the food body, the attention must be highly concentrated on avoiding all kinds of threats for the human consumption later on. The Quality Control must have the eyes and mind everywhere to see what is happening that no mistakes be made - by accident or - sometimes - even intentionally. The best and reliable Quality Control is done by Inspectors who know their job thoroughly and can follow the whole process from the raw material to the finished products. Thus, it is important to recruit Quality Control Inspectors who can do all this right and have the basic knowledge.

\subsection{Study 6: The combined effects of ambivalence and involvement on satisfaction and consumption/loyalty}

This study tests the different and combined roles of consumer involvement and ambivalence about fish products in the satisfaction-consumption/repurchase loyalty relationship.

This study is based on the following perspectives:

(1) Consumers have both positive and negative evaluations about perceived quality as well as the perceptions of food risks. Therefore, they have conflict thoughts, feelings and emotions or ambivalence about the products, which causes several negative consequences in consumer satisfaction, involvement and consumption toward the products $[38,42]$. Ambivalence also damages the satisfaction feelings which decreases the satisfaction strength (predictive power) [43]. 
(2) Consumers involve fish products because the products are good for their health [44]. Involvement is integrated as a motivational factor which mediates the relationship between satisfaction and loyalty/consumption [45]. Involvement moderates the satisfaction-loyalty relationship because consumers' evaluations (satisfaction) based on higher involvement/importance are often stronger than ones based on lower involvement [46,47].

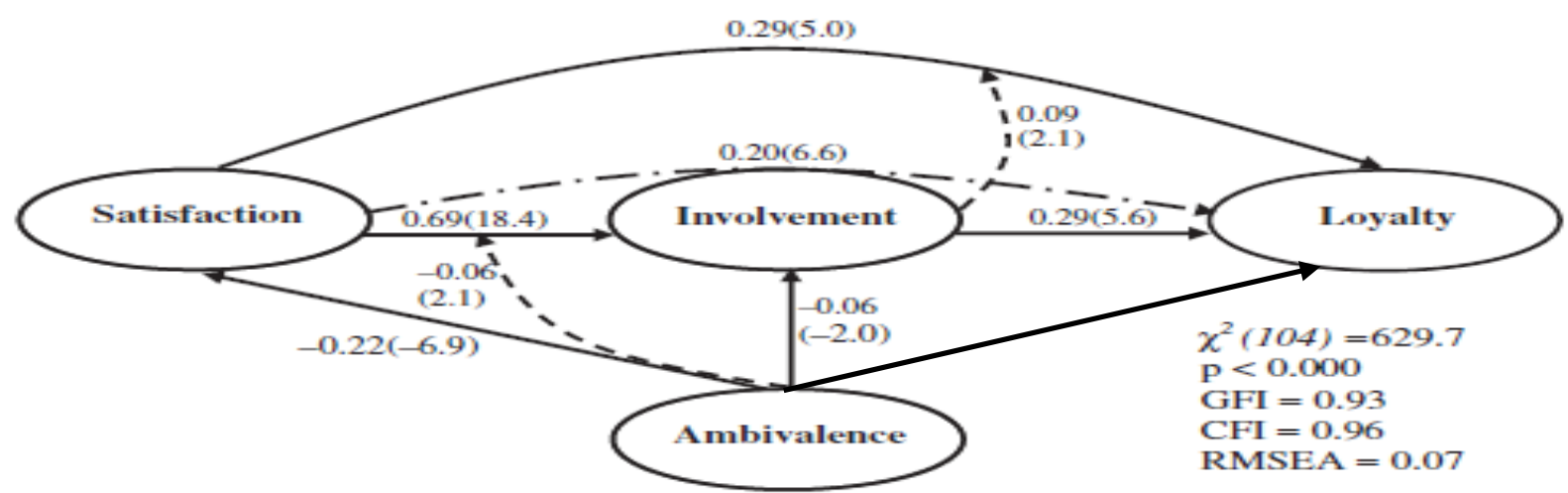

Figure 4. The effects of involvement and ambivalence

The results indicate that satisfaction has both positive direct and indirect effects on repurchase loyalty via involvement. Ambivalence has negative direct effects on both satisfaction and involvement, but does not directly influence repurchase loyalty. Empirical evidence also reveals that ambivalence and involvement are both moderators in the satisfactionrepurchase loyalty relationship. However, the moderating mechanisms of the two constructs in this relationship are different. While involvement moderates positively the direct effect of satisfaction on repurchase loyalty, ambivalence moderates negatively the indirect effect of satisfaction on repurchase loyalty via involvement. This result means that the indirect effect of satisfaction on repurchase loyalty through involvement is weaker under high ambivalence than low ambivalence.

These findings suggest that, for the goal of increasing repurchasing rate, food companies should focus on consolidating consumer satisfaction and involvement as well as reducing their ambivalence. First, this emphasizes rejecting the sources of ambivalent feelings (e.g. negative feelings) such as reducing perceptions of risks. These policies should go along with giving consumers an engagement about the quality guarantee, communicating positive aspects related to the products (e.g. safe, healthy, quality, stability and so on) [48], but more importantly keeping these actions consistently. Specifically, ambivalent consumers would be targets for persuasive messages to increase the value of their positive beliefs and/or decrease their negative beliefs regarding buying or using a particular product while long-term efforts are needed for consumers with only negative beliefs, first creating ambivalent attitudes and then converting them to positive ones at a later point [38]. Second, this research indicates that marketers could improve their marketing knowledge not only by knowing the degree to which repurchase behavior is driven by individual satisfaction, but also by understanding the psychological structure and the process of how satisfaction is related to repurchase behavior, especially the role of food involvement as a motivational and moderating factor [45] as well as the barrier nature of ambivalence. 


\section{DISCUSSIONS AND FUTURE RESEARCH}

\subsection{Discussions}

As a summary, based on the perspectives of perceived quality and food risks in broader theories of Perceived Quality Approximation, Total Food Quality Model and Attitude Strength, this paper investigates and reports the different sources and dimensions of perceived quality and perceived food risks affecting consumer attitudes/satisfaction and consumption in fish consumption context in Vietnam. This paper illustrated different reasons for and the sources of perceived quality and food risks and their effects on consumer satisfaction and consumption. It has also proven that both perceived quality and perceived food risk are multidimensional constructs and affect consumer satisfaction and consumption in different ways. Finally, both consumer ambivalence and health involvement have been proven to affect consumer satisfaction and consumption in a complex mechanism.

In a developing country such as Vietnam, consumers are faced with a low and unreliable quality of food/fish supplied by the local markets. Thus, the number of victims due to food poisoning has been considerable in recent years. Even though perceived quality and risk is important constructs in marketing $[14,49]$, only a few studies investigate how they affect and interact with satisfaction in influencing consumers' repurchase loyalty or consumption (e.g. Grewal, et al. [50]; Tsiros and Heilman [51]). Furthermore, consumer knowledge are suggested as important factors to understand perceived risk, understand how consumers manage to reduce risks [52,53] as well as to increase consumer satisfaction [54,55] and consumer consumtion/loyalty [56,57]. Thus, the role of consumer knowledge and its interaction with perceived risk on satisfaction, consumption/loyalty and on the satisfaction-loyalty relationship is also important understandings. For the parallel presence of both positive ans negative aspects of food quality and risk, consumers who involve their health may feel ambivalent about food, and its consequences depends much on consumer knowledge and skills in evaluating, choosing, preparing and cooking fish. Thus, health involvement and ambivalence are integrated in the model as factors which may impact on consumer satisfaction, loyalty and the relationship between these two contructs. Generally, this paper has made an effort to generate a integated model that draws a comprehensive picture to understand consumer perceived food quality and risk as well as relevant psychological factors influencing consumer attitudes, satisfaction and consumption/loyalty at least in the context of Vietnamese food/fish consumption. From the findings, this paper calls for managers' attention on consumer perceived quality, food risks and their reasons and sources to research, design, process and control food product quality and risks to fulfill consumer satisfaction and increase consumer consumption/loyalty.

\subsection{Future research}

The findings and implications of each study and the integrated conceptual model presented in this paper must be viewed in light of its limitations. This paper will discuss these limitations and suggest directions for future research.

Perceived food quality has so far been discussed and investigated on the basis of cumulative mean evaluations that consumers perceived at the time of investigating. However, those evaluations might change time by time or uncertain. The certainty or uncertainty of food quality and its levels may cause different consequences on consumer feelings, 
emotions and behaviors. Thus, a key question for managers and researchers is as follows:

Research question 1: Do the certainty or stability of perceived food quality affect and/or interact with consumer satisfaction to increase consumption/ loyalty? Food quality as perceived by consumers is often uncertain, which may generate consumers' unconfident evaluations. This may damage consumer satisfaction feelings during consumption and decrease the consumption of the product. Therefore, food quality assurance or control or keeping food quality constantly at least fulfilling established standards or consumer expectations may be important to consolidate consumer satisfaction and increase the consumption. Because different dimensions of food quality are perceived by consumers and the acceptance of assuring and controlling all these dimensions may cost much money, the price of food products may be an issue for both processors and consumers at least for domestic markets. So far, perceived quality and price have been discussed independently, however whether perceived food quality and price can get together and interact with each other to influence consumer satisfaction and consumption is an under covered issue. Thus, the next question is:

Research question 2: Do perceived food quality and perceived price interact to influence consumer satisfaction and consumption? Although many researchers have agreed that perceived price is an important determinant of consumers behaviors, little empirical research has investigated the influence of perceived price on consumer behaviors in the food industry. Some researchers imply that perceived price may moderate the relationship between perceived quality, consumer satisfaction and consumption [8,58]. Specifically, when consumers perceive the price to be reasonable, their satisfaction with food quality will increase, and may enhance the effect of food quality on consumer satisfaction. The addition of the interaction between perceived food quality and perceived price may contribute to explaining better consumer satisfaction and consumption toward the food products. In addition, food quality and safety or risk has discussed thorough in the paper as two sides of a coin. Although they have been discussed so far as independent constructs rather than related to each other, consumers can not have a good meal if they perceive the food as a risky choice, and thus they may stop eating it temporarily if they perceive that risk higher than a certain threshold. It means that food quality and risk may interact to influence consumer satisfaction and consumption. However, we only have a little knowledge about how perceived food quality and perceived risk interact to influence consumer behaviors in the literature. Thus, the next question is:

Research question 3: Do perceived food quality and perceived risk interact to influence consumer satisfaction and consumption? A few studies explore the moderator role of perceived risk in the link between product evaluations and choice [49,59]. Because perceived food risk often relates to losses and future uncertainty consequences [52] as well as damaging perceived benefits [60], it is reasonable to anticipate that when consumers perceive high levels of perceived food risk, their expectations and evaluations of food quality are formed with less stability, which implies that the predictive strength of perceived quality on consumer satisfaction and consumption decreases when perceived risk increases. This knowledge is important for both food marketing in building risk-reducing strategy and Quality Control in convincing food processors conducting the established standards of food quality. We have discussed the interaction between perceived quality and perceived risk as overall constructs. However, different forms of risk as well as different dimensions of perceived food quality exist in the 
literature $[11-13,61]$. Therefore, the next question is that:

Research question 4: What form of risk interacts with what dimension of perceived quality to influence consumer satisfaction and consumption? As discussed in the Introduction, perceived food quality includes the four dimensions: taste, nutrition, safety and convenience, while perceived food risk includes the aspects of performance, health, psychological, social, time and effort and financial risks. Therefore, the possibility for the interaction of each aspect of food risk and perceived food quality may be different. On the basic of their nature and concepts, it could be expected there are the interaction pairs as follows: performance risk - taste quality; nutrition quality - health risk; safety quality - health risk; safety quality - psychological risk; safety quality social risk; convenience quality - time and effort risk and the like. The exploration of each interaction pair may give significant understandings to call for managerial attention in building marketing messages to confirm product quality dimensions and in realizing the necessity of building the system of risk control for the products. When perceived risk exceeds individual tolerance levels, consumers often manage to reduce the negative effect of risk by methods such as obtaining additional information [53], or careful evaluations of alternatives and product trials $[52,62]$. It has for a long time been suggested that increasing consumers' knowledge is an important strategy to reduce perceived risk because more information or experiences result in a learning process that leads consumers to perceive less risk [63]. The findings show that consumer overall knowledge can help to decrease the negative effects of perceived food risk on consumer satisfaction and consumption. However, different facets of knowledge exist in the literature [64] and the different dimensions of knowledge (e.g., such as declarative, procedural, schematic knowledge or knowledge about product class and so on) have been shown to have unequal effects on different outcome variables $[55,65]$. Thus, the next question is as follows:

Research question 5: How can each kind of consumer knowledge help to decrease the negative effects of food risks? In relation to food risks and their sources, it is possible to argue that if consumers have knowledge of how to evaluate fresh food quality, they can avoid the risk of health, financial and performance risks; or if they have good skills of preparing and cooking, the performance, financial and psychological or even social risks may decrease; and so on. A study that investigates the role of each kind of knowledge in reducing food risks may be important because it could provide useful information for marketers in designing communication program to educate consumers with the relevant knowledge.

However, food quality and safety are credence attributes, which are not easily assessed by consumers [66]. Consumers may not detect the presence or absence of this attribute even after purchase and use [25]. Therefore, besides educating consumers with relevent knowledge, other efforts need to be generated to convince consumers trust in food quality and safety. Food trust is considered as a value which dominate consumers' attitude toward food or food improvement. Food quality improvement is a desire consumers considers while consuming food. When they trust in food or food improvement, they will have a positive attitude toward this food. Therefore, the role of Quality Control should be enhanced and quality programs should be built to solve the problems of fishing vessels, farmers, processors, marketing sectors and the consumers, and to increase the consumer's security in health and nutritional values. It may be that the consumer's concerns are not taken directly 
into consideration by the quality programs, but processors, retailers or the civil servants should represent their interests through marketing strategies. A consequence of these policies is the increase of quality control and market transparency. However, while ethical issues in business is popular nowadays, such quality programs and the increase of Quality

\section{FURTHER READINGS}

Cong, L.C., Olsen, S.O. \& Tuu, H.H. (2013). The roles of ambivalence, preference conflict and family identity: A study of food choice among Vietnamese consumers. Food Quality and Preference, 28, 92-100.

Honkanen, P., Olsen, S.O., Bass, V. \& Tuu, H.H. (2012). Reflective and impulsive influences on unhealthy snacking. The moderating effects of food related self-control. Appetite, 58, 616-622.

Tuu, H.H. \& Olsen, S.O. (2010). Ambivalence and involvement in the satisfaction-repurchase loyalty Eelationship. Australasian Marketing Journal, 18, 151-158.

Tuu, H.H. Olsen, S.O. \& Linh, P.T.T. (2011). The moderator effects of perceived risk, objective knowledge and certainty in the satisfactionloyalty relationship. Journal of Consumer Marketing, 28 (5), 363-375.

Tuu, H.H. \& Olsen, S.O. (2012). Certainty, risk and knowledge in the satisfaction-purchase
Control are always big challenges for Vietnamese food industry.

\section{ACKNOWLEDGEMENT}

The authors thank to Mr. Herby Neubacher as an expert in seafood area. He has given valuable comments and significantly contributed to the presentations.

intention relationship in a new product experiment. Asia Pacific Journal of Marketing and Logistics, 24(1), 78-101.

Tuu, H.H., Olsen, S.O., Thao, D.T. \& Anh, N.T.K. (2008). The role of norms in explaining attitudes, intention and consumption of a common food (fish) in Vietnam. Appetite, 51, 546-551.

Hồ Huy Tựu, Nguyễn Thị Mỹ Hiền \& Lê Nguyễn Hậu (2009). Các nhân tố ảnh hưởng đến sự hài lòng: Cấu trúc đa chiều của chất lượng thủy sản cảm nhận. Tạp chí Khoa hoc Công nghệ Thủy sản, Trường Đại học Nha Trang, 03, 208215.

Hồ Huy Tựu (2011). Phân tích thái độ của người tiêu dùng đối với sản phẩm cá. Tạp chí Khoa hoc và Công nghệ Thủy sản, Trường Đại học Nha Trang, 2, 11-18. 


\section{Các hàm ý ứng dụng đối với marketing, đảm bảo và kiểm soát chất lượng thực phẩm: cách tiếp cận dựa vào phân tích thái độ và hành vi tiêu dùng}

- Hồ Huy Tựu $\mathrm{a}^{*}$

- Lê Nguyên Hậu

(a) Đại học Nha Trang, Khánh Hòa, Việt Nam

(b) Trường Đại học Bách khoa-ĐHQG TpHCM, Việt Nam

*Email: tuu_hohuy@yahoo.com

\section{TÓM TÁT}

Mục tiêu nghiên cứu - Bài báo này trình bày ý tưởng rằng quản trị và kiểm soát chất lượng thực phẩm nên được dựa trên các quan điểm định hướng marketing. Bài báo hướng đến mục tiêu khám phá các dấu hiệu, lý do, tiêu chí và các nguồn làm nảy sinh các cảm nhận chất lượng và rủi ro thực phẩm, cũng như kiểm định ảnh hưởng của chúng đến sự thỏa mãn và mức độ tiêu dùng của người tiêu dùng đối với thực phẩm (cá) ở Việt Nam. Sau cùng, bài báo đưa ra một số đề nghị cho nghiên cứu tiếp theo trong cả hai lĩnh vực marketing và kiểm soát chất lượng thực phẩm.

Phương pháp nghiên cứu - Bài báo dựa trên kết quả của nhiều nghiên cứu định lượng sử dụng nhiều nguồn dũ liệu điều tra khác nhau được thu thập ở nhiều tỉnh thành trên cả nước, và sử dụng nhiều phương pháp khác nhau để phân tích dữ liệu, kiểm định các cấu trúc khái niệm, giả thuyết và mô hình đề xuất.

Các phát hiện - Trước tiên, bài báo chỉ ra rằng các cảm nhận về dinh dương và độ ngon chiếm

giữ tỷ lệ cao nhất giải thích cho các thái độ tích cực của người tiêu dùng (chất lượng cảm nhận tích cực), trong khi các cảm nhận về sự an toàn và cảm giác tiêu cực nổi trội trong việc giải thích cho các thái độ tiêu cực (các cảm nhận rủi ro thực phẩm). Người tiêu dùng có nhiều lý do tích cực (tiêu cực) hơn sẽ có mức tiêu dùng cao (thấp) hơn. Thứ hai, cảm nhận chất lượng thực phẩm dưới góc độ là một cấu trúc khái niệm đa chiều được tìm thấy có ảnh hưởng dương, trong khi các cảm nhận tiêu cực có tác động âm đến sự thỏa mãn của người tiêu dùng. Giá cảm nhận không có ảnh hưởng đến sự thỏa mãn nhưng có ảnh hưởng dương đến chất lượng cảm nhận. Kết quả nghiên cứu cũng chỉ ra có bốn nhóm lý do chính gây ra các cảm nhận rủi ro thực phẩm xuất phát từ nhà sản xuất, người bán hàng, người tiêu dùng và chính sản phẩm. Các cảm nhận rủi ro thực phẩm được phát hiện có ảnh hưởng gián tiếp âm đến mức tiêu dùng thông qua sự thỏa mãn, đồng thời điều tiết âm mối quan hệ thỏa mãn - mức tiêu dùng. Tuy nhiên, tác động của các cảm nhận rủi ro sẽ yếu đi khi kiến thức của người tiêu dùng gia tăng. Cuối cùng, cảm xúc lẫn lộn được tìm thấy có ảnh hưởng trực tiếp âm lên cả sự thỏa mãn lẫn quan tâm sức khỏe của người tiêu dùng, và cả hai 
cấu trúc khái niệm cảm xúc lẫn lộn và quan tâm sức khỏe cũng có các tác động điều tiết lên mối quan hệ thỏa mãn - mức tiêu dùng theo một cơ chế khá phức tạp.

Các hàm ý quản trị - Các nhà quản trị và marketing nên chú ý đến các lý do giải thích cho các thái độ và mức độ tiêu dùng của người tiêu dùng, và nên có một quan điểm đa chiều về chất lượng và rủi ro thực phẩm. Các chiến lược marketing, mà giảm thiểu các rủi ro cho người tiêu dùng, và dạy họ các kiến thức phù hợp có lẻ là các chiến lược hiệu quả để gia tăng mức tiêu dùng. Đối với kiểm soát chất lượng, những người thực thi phải hiểu không chỉ các tiêu chuẩn cảm quan được thiết lập mà còn phải hiểu, nếu có thể, các kỳ vọng của người tiêu dùng về các mức cảm quan chất lượng thực phẩm của người tiêu dùng ở các thị trường mục tiêu mà các công ty theo đuổi. Kiểm soát chất lượng cũng phải hiểu các hệ thống truy nguyên nguồn gốc từ các nguồn nguyên liệu cho đến các thành phẩm, tìm kiếm và ngăn chặn các phương pháp và thủ thuật mà người sản xuất, người chế biến và người bán sử dụng để né tránh hoặc qua mặt các quy định chất lượng do sự thiếu hụt các nguồn nguyên liệu đúng tiêu chuẩn. Vì vậy, việc tuyển dụng được các nhân

\section{REFERENCES}

[1]. M. A. S. Alonso, P. A. M. Gallego, and J.-P. L. Mangin, "Testing a model of perceived food quality determinants," Journal of International Food \& Agribusiness Marketing, vol. 17, pp. 9-33, 2005.

[2]. G. G. Klaus, B. Søren, B. Lone, S. Elin, and A. N. Niels, "A survey of Danish consumers' purchase of seafood," Aarthus School of Business 1996.

[3]. C. A. Reeves and D. A. Bednar, "Defining quality: alternatives and implications," Academy of management Review, vol. 19, pp. 419-445, 1994. viên kiểm soát chất lượng có kiến thức chuyên môn cũng như có khả năng thực thi các điều này là rất quan trọng.

Hạn chế và nghiên cứu tiếp theo - Bài báo chỉ tập trung vào các sản phẩm cá. Các nghiên cứu tiếp theo nên mở rộng đến các loại thực phẩm khác và cố gắng trả lời các câu hỏi nghiên cứu sau: Liệu sự bất định của chất lượng cảm nhận có ảnh hưởng đến hoặc tương tác với sự thỏa mãn của người tiêu dùng để gia tăng mức tiêu dùng? Liệu cảm nhận chất lượng và cảm nhận giá có tương tác để ảnh hưởng đến sự thỏa mãn và mức tiêu dùng? Liệu cảm nhận chất lượng và rủi ro thực phẩm có tương tác để ảnh hưởng đến sự thỏa mãn và mức tiêu dùng? Dạng cảm nhận rủi ro nào có thể tương tác với khía cạnh cảm nhận chất lượng nào để ảnh hưởng đến sự thỏa mãn và mức tiêu dùng? Mỗi loại kiến thức khách hàng có khả năng ra sao trong việc giúp giảm thiểu các tác động tiêu cực của các rủi ro thực phẩm cảm nhận? Kiểm soát và các chương trình chất lượng nên được xây dựng ra sao để giải quyết các vấn đề nảy sinh từ các đội tàu khai thác, hộ nuôi, nhà chế biến, các khu vực marketing và người tiêu dùng, và gia tăng sự đảm bảo cho người tiêu dùng trong cả chất lượng dinh dưỡng lẫn sức khỏe.

[4]. L. A. Morgan, "The importance of quality," Perceived quality, pp. 61-4, 1985.

[5]. D. A. Garvin, "What does "product quality" really mean," Sloan management review, vol. $1,1984$.

[6]. R. L. Oliver, "A cognitive model of the antecedents and consequences of satisfaction decisions," Journal of marketing research, pp. 460-469, 1980.

[7]. K. G. Grunert, "Food quality and safety: consumer perception and demand," European Review of Agricultural Economics, vol. 32, pp. 369-391, 2005. 
[8]. V. A. Zeithaml, "Consumer perceptions of price, quality, and value: a means-end model and synthesis of evidence," The Journal of Marketing, pp. 2-22, 1988.

[9]. P. A. Oude Ophuis and H. Van Trijp, "Perceived quality: a market driven and consumer oriented approach," Food quality and Preference, vol. 6, pp. 177-183, 1995.

[10]. V. A. Zeithaml, A. Parasuraman, and A. Malhotra, "Service quality delivery through web sites: a critical review of extant knowledge," Journal of the academy of marketing science, vol. 30, pp. 362-375, 2002.

[11]. J. G. Anderson and J. L. Anderson, "Seafood quality: issues for consumer researchers," Journal of Consumer Affairs, vol. 25, pp. 144163, 1991.

[12]. J. B. Gotlieb, D. Grewal, and S. W. Brown, "Consumer satisfaction and perceived quality: complementary or divergent constructs?," Journal of applied psychology, vol. 79, p. 875, 1994.

[13]. K. G. Grunert, L. Bredahl, and K. Brunsø, "Consumer perception of meat quality and implications for product development in the meat sector-a review," Meat science, vol. 66, pp. 259-272, 2004

[14]. S. O. Olsen, "Comparative evaluation and the relationship between quality, satisfaction, and repurchase loyalty," Journal of the Academy of Marketing Science, vol. 30, pp. 240-249, 2002.

[15]. L. Bredahl and K. G. Grunert, "Determinants of the consumption of fish and shellfish in Denmark: an application of the theory of planned behavior," in International Seafood Conference: Seafood from producer to consumer, integrated approach to quality, 1997.

[16]. S. O. Olsen, "Antecedents of seafood consumption behavior: an overview," Journal of Aquatic Food Product Technology, vol. 13, pp. 79-91, 2004.

[17]. M.-F. Chen and H.-L. Li, "The consumer's attitude toward genetically modified foods in Taiwan," Food Quality and Preference, vol. 18, pp. 662-674, 2007.

[18]. G. Foxall, S. Leek, and S. Maddock, "Cognitive Antecedents of Consumers» Willingness to Purchase Fish Rich in Polyunsaturated Fatty Acids (PUFA)," Appetite, vol. 31, pp. 391-402, 1998.

[19]. K. Roininen, L. Lähteenmäki, and H. Tuorila, "Quantification of consumer attitudes to health and hedonic characteristics of foods," Appetite, vol. 33, pp. 71-88, 1999.

[20]. C. M. Gempesaw, R. Bacon, C. R. Wessells, and A. Manalo, "Consumer perceptions of aquaculture products," American Journal of Agricultural Economics, vol. 77, pp. 13061312, 1995.

[21]. S. Leek, S. Maddock, and G. Foxall, "Situational determinants of fish consumption," British food journal, vol. 102, pp. 18-39, 2000.

[22]. S. O. Olsen, "Understanding the relationship between age and seafood consumption: the mediating role of attitude, health involvement and convenience," Food Quality and Preference, vol. 14, pp. 199-209, 2003.

[23]. A. Steptoe, T. M. Pollard, and J. Wardle, "Development of a measure of the motives underlying the selection of food: the food choice questionnaire," Appetite, vol. 25, pp. 267-284, 1995.

[24]. P. Rozin and T. A. Vollmecke, "Food likes and dislikes," Annual review of nutrition, vol. 6, pp. 433-456, 1986.

[25]. A. M. Angulo and J. M. Gil, "Risk perception and consumer willingness to pay for certified beef in Spain," Food Quality and Preference, vol. 18, pp. 1106-1117, 2007. 
[26]. R. M. Yeung and J. Morris, "Consumer perception of food risk in chicken meat," Nutrition \& Food Science, vol. 31, pp. 270279, 2001.

[27]. R. N. Stone and K. Grønhaug, "Perceived risk: further considerations for the marketing discipline," European Journal of marketing, vol. 27, pp. 39-50, 1993.

[28]. J. Jacob and L. B. Kaplan, "The Components of Perceived Risk," in SV - Proceedings of the Third Annual Conference of the Association for Consumer Research, 1972, pp. 382-393.

[29]. H. H. Tuu, S. O. Olsen, and P. T. T. Linh, "The moderator effects of perceived risk, objective knowledge and certainty in the satisfactionloyalty relationship," Journal of Consumer Marketing, vol. 28, pp. 363-375, 2011.

[30]. G. A. Churchill Jr and C. Surprenant, "An investigation into the determinants of customer satisfaction," Journal of marketing research, pp. 491-504, 1982.

[31]. C. Fornell, M. D. Johnson, E. W. Anderson, J. Cha, and B. E. Bryant, "The American customer satisfaction index: nature, purpose, and findings," The Journal of Marketing, pp. 7$18,1996$.

[32]. F. F. Reichheld, "The Loyalty Effect, Harvard Business School Press," Boston, MA, 1996.

[33]. J. Rowley and J. Dawes, "Disloyalty: a closer look at non-loyals," Journal of Consumer Marketing, vol. 17, pp. 538-547, 2000.

[34]. R. L. Day, "Modeling choices among alternative responses to dissatisfaction," Advances in consumer research, vol. 11, pp. 496-499, 1984.

[35]. A. H. Eagly and S. Chaiken, The psychology of attitudes: Harcourt Brace Jovanovich College Publishers, 1993.
[36]. R. E. Petty and J. T. Cacioppo, "Communication and persuasion: Central and peripheral routes to attitude change," 1986.

[37]. K. Jonas, M. Diehl, and P. Brömer, "Effects of attitudinal ambivalence on information processing and attitude-intention consistency," Journal of Experimental Social Psychology, vol. 33, pp. 190-210, 1997.

[38]. S. O. Olsen, J. Wilcox, and U. Olsson, "Consequences of ambivalence on satisfaction and loyalty," Psychology \& Marketing, vol. 22, pp. 247-269, 2005.

[39]. M. Fishbein and I. Ajzen, Belief, attitude, intention and behavior: An introduction to theory and research, 1975.

[40]. G. B. Voss, A. Parasuraman, and D. Grewal, "The roles of price, performance, and expectations in determining satisfaction in service exchanges," The Journal of Marketing, pp. 46-61, 1998.

[41]. R. M. Yeung and W. M. Yee, "Multidimensional analysis of consumer-perceived risk in chicken meat," Nutrition \& Food Science, vol. 32, pp. 219-226, 2002.

[42]. S. Costarelli and P. Colloca, "The moderation of ambivalence on attitude-intention relations as mediated by attitude importance," European Journal of Social Psychology, vol. 37, pp. 923933, 2007.

[43]. M. Conner and P. Sparks, "Ambivalence and attitudes," European review of social psychology, vol. 12, pp. 37-70, 2002.

[44]. S. Olsen, "Consumer involvement in seafood as family meals in Norway: an application of the expectancy-value approach," Appetite, vol. 36, pp. 173-186, 2001.

[45]. S. O. Olsen, "Repurchase loyalty: the role of involvement and satisfaction," Psychology \& Marketing, vol. 24, pp. 315-341, 2007. 
[46]. C. J. Armitage and M. Conner, "Efficacy of the theory of planned behaviour: A meta-analytic review," British journal of social psychology, vol. 40, pp. 471-499, 2001.

[47]. M. Chandrashekaran, K. Rotte, S. S. Tax, and R. Grewal, "Satisfaction strength and customer loyalty," Journal of Marketing Research, vol. 44, pp. 153-163, 2007.

[48]. R. Povey, B. Wellens, and M. Conner, "Attitudes towards following meat, vegetarian and vegan diets: an examination of the role of ambivalence," Appetite, vol. 37, pp. 15-26, 2001.

[49]. M. C. Campbell and R. C. Goodstein, "The moderating effect of perceived risk on consumers' evaluations of product incongruity: Preference for the norm," Journal of Consumer Research, vol. 28, pp. 439-449, 2001.

[50]. D. Grewal, G. R. Iyer, J. Gotlieb, and M. Levy, "Developing a deeper understanding of postpurchase perceived risk and behavioral intentions in a service setting," Journal of the Academy of Marketing Science, vol. 35, pp. 250-258, 2007.

[51]. M. Tsiros and C. M. Heilman, "The effect of expiration dates and perceived risk on purchasing behavior in grocery store perishable categories," Journal of Marketing, vol. 69, pp. 114-129, 2005.

[52]. G. R. Dowling and R. Staelin, "A model of perceived risk and intended risk-handling activity," Journal of consumer research, pp. 119-134, 1994.

[53]. V.-W. Mitchell, "Consumer perceived risk: conceptualisations and models," European Journal of marketing, vol. 33, pp. 163-195, 1999.

[54]. Z. Pieniak, W. Verbeke, I. Vermeir, K. Bruns $\oslash$, and S. O. Olsen, "Consumer interest in fish information and labelling: exploratory insights," Journal of International Food \& Agribusiness Marketing, vol. 19, pp. 117-141, 2007.

[55]. V. V. Cordell, "Consumer knowledge measures as predictors in product evaluation," Psychology \& Marketing, vol. 14, pp. 241-260, 1997.

[56]. S. J. Bell, S. Auh, and K. Smalley, "Customer relationship dynamics: service quality and customer loyalty in the context of varying levels of customer expertise and switching costs," Journal of the Academy of Marketing Science, vol. 33, pp. 169-183, 2005.

[57]. J.-S. Chiou and C. Droge, "Service quality, trust, specific asset investment, and expertise: direct and indirect effects in a satisfactionloyalty framework," Journal of the Academy of Marketing Science, vol. 34, pp. 613-627, 2006.

[58]. A. Caruana, A. H. Money, and P. R. Berthon, "Service quality and satisfaction-the moderating role of value," European Journal of marketing, vol. 34, pp. 1338-1353, 2000.

[59]. Z. Gürhan-Canli and R. Batra, "When corporate image affects product evaluations: the moderating role of perceived risk," Journal of Marketing Research, vol. 41, pp. 197-205, 2004.

[60]. A. Saba and F. Messina, "Attitudes towards organic foods and risk/benefit perception associated with pesticides," Food quality and preference, vol. 14, pp. 637-645, 2003.

[61]. M. McCarthy and S. Henson, "Perceived risk and risk reduction strategies in the choice of beef by Irish consumers," Food Quality and Preference, vol. 16, pp. 435-445, 2005.

[62]. J. Cho and J. Lee, "An integrated model of risk and risk-reducing strategies," Journal of Business Research, vol. 59, pp. 112-120, 2006. 
[63]. T. Roselius, "Consumer rankings of risk reduction methods," The journal of marketing, pp. 56-61, 1971.

[64]. J. W. Alba and J. W. Hutchinson, "Dimensions of consumer expertise," Journal of consumer research, pp. 411-454, 1987.
[65]. C. W. Park, D. L. Mothersbaugh, and L. Feick, "Consumer knowledge assessment," Journal of Consumer Research, pp. 71-82, 1994.

[66]. E. S. Andersen and K. Philipsen, "The evolution of credence goods in customer markets: exchanging "pigs in pokes"," in DRUID Winter Seminar, Middelfart, 1998. 